\title{
Hepatitis Viral, CTCAE
}

National Cancer Institute

\section{Source}

National Cancer Institute. Hepatitis Viral, CT CAE. NCI Thesaurus. Code C143543.

A disorder characterized by a viral pathologic process involving the liver parenchyma. 